\title{
Participation Patterns of Exercise among People with Disabilities in South Korea: Emphasis on 2014 and 2017 Survey Data
}

\author{
Joon-Sik Kim ${ }^{1}$, Jungjun Lim ${ }^{1}$ \\ ${ }^{1}$ Department of Physical Education, College of Education, Seoul National University, Seoul 08826, Korea
}

\begin{abstract}
Background/Objectives: Although many studies have reported that physical activity (PA) and exercise have significant positive effects on various health aspects, very few have classified persons by their disability types and investigated PA participation patterns, along with obstacle factors. This study aimed to analyze and compare exercise participation patterns and obstacle factors by classifying a large sample of Koreans with various disability types. Methods/Statistical analysis: Data on regular exercise participation patterns and barriers to participation were collected in 2014 and 2017 from 11,815 persons with disabilities (ages 0-99 years) residing in South Korea. A chi-square test was used to examine differences in the subjects' evaluation of health status, weekly exercise frequency, preferred place, and reasons for non-participation. A repeated measures ANOVA was performed for comparing exercise time per session, and post-hoc analysis was used to confirm differences based on disability types. Findings: The analysis showed significantly different response rates based on the disability type for subjective health status, regular exercise participation, reasons for non-participation, weekly exercise frequency, and preferred exercise place $(p<.001)$. Conversely, for exercise time per session, the difference between disability types was not statistically significant $(p>.05)$. Improvements/Applications: In conclusion, regardless of the disability types, the regular exercise participation rate of people with disabilities was significantly lower than that of healthy adults in South Korea. Additionally, this is a basic study confirming that exercise participation patterns and obstacles differ depending on the type of disability. Accordingly, future public health policies should closely identify the characteristics of each type of disability to help promote PA for all.
\end{abstract}

\section{Index Terms}

Physical activity patterns, Exercise, People with disabilities, Survey, Disability types

\footnotetext{
Corresponding author : Jungjun Lim

Imjung87@snu.ac.kr

- Manuscript received April 15, 2021.

- Revised May 14, 2021 ; Accepted June 1, 2021.

- Date of publication June 30, 2021
}

(c) The Academic Society of Convergence Science Inc.

2619-8363 $\odot 2019$ IJBSA. Personal use is permitted, but republication/redistribution requires IJBSA permission. 


\section{INTRODUCTION}

Many studies have reported significant positive effects of physical activity (PA) and exercise on various aspects, such as reducing all-cause mortality [1,2], preventing chronic diseases [2-5], and maintaining health conditions [3,5-7]. To achieve these, both the American College of Sports Medicine (ACSM) and PA guidelines for Americans have recommended that adults, with and without disabilities, should participate in at least 150 minutes of moderate-intensity exercise or 75 minutes of highintensity PA per week $[8,9]$.

However, some studies have reported that only about half of the people with disabilities achieve PA recommendations owing to their physical limitations $[10,11]$ and lower fitness levels compared to the general population [12], and are 50\% more likely to be afflicted by chronic diseases [10]. Hence, there is an increasing need for achieving recommendations on PA and regular exercise [13]. To increase participation, some studies have reported the need for additional social and environmental support, such as disabilities-related facilities and assistance [14,15]. However, despite the demand and support required for PA, and the fact that participation may vary depending on the type of disability, very few studies have classified persons by their disability types and investigated PA participation patterns, along with obstacle factors.

Therefore, this study aims to analyze exercise participation patterns and obstacles by classifying a large sample of Koreans by their disability type.

\section{MATERIALS AND METHODS}

\section{A. Participants and procedure}

Based on Article 31 of Korea's Welfare Law for Persons with Disabilities, its Ministry of Health and Welfare has been regularly conducting surveys every five years since 1980 and every three years since 2005 , to investigate the living conditions and welfare needs of people with disabilities. This study selected 15 types of disabilities from all age groups in 250 survey areas in South Korea and pursued the following order: survey-guideline development, preliminary survey, investigator training, field survey, and data processing, using data from 2014 and 2017 for the analysis. The detailed survey included households, types of disabilities, health and healthcare, daily life support, disability assistive devices, education, employment and work life, sociocultural and leisure activities, marital life, life satisfaction, housing, welfare services, and economic status.

\section{B. Statistical analysis}

A chi-square test was used to analyze health status, frequency of exercise/PA, preferred place of exercises, and reasons for non-participation. A repeated measures ANOVA was performed for comparing exercise time per session, and Bonferroni post-hoc analysis was used to confirm differences by disability types. All statistical analyses were performed using STATA (SE) 12.0 (Stata Corp., College Station, Tx, USA), and the statistical significance level was set at $\mathrm{p}<0.05$.

\section{RESULTS AND DISCUSSION}

Of the 15 disability types investigated, 11,815 persons from four types-6,683 persons with physical impairment, 1,376 with brain lesions, 2,897 with hearing and/or visual impairments, and 859 with intellectual disabilities-were finally selected, and their health status and exercise participation patterns were analyzed.

A questionnaire on subjective health status based on the type of disability is presented in Table 1.

Table 1. Subjective health status according to the type of disability.

\begin{tabular}{|c|c|c|c|c|}
\hline $\begin{array}{l}\text { Type of } \\
\text { disability }\end{array}$ & $\begin{array}{c}\text { Good } \\
(\%)\end{array}$ & $\begin{array}{c}\text { Average } \\
(\%)\end{array}$ & $\begin{array}{l}\mathrm{Bad} \\
(\%)\end{array}$ & $\begin{array}{c}\text { Chi-square } \\
\text { p-value }\end{array}$ \\
\hline $\begin{array}{c}\text { Physical } \\
\text { impairment }\end{array}$ & $\begin{array}{c}868 \\
(12.9)\end{array}$ & $\begin{array}{l}2,145 \\
(32.1)\end{array}$ & $\begin{array}{l}3,670 \\
(54.9)\end{array}$ & \multirow{4}{*}{$\mathrm{P}<0.001$} \\
\hline $\begin{array}{l}\text { Brain } \\
\text { lesions }\end{array}$ & $\begin{array}{c}70 \\
(5.0)\end{array}$ & $\begin{array}{c}241 \\
(17.5)\end{array}$ & $\begin{array}{l}1,065 \\
(77.4)\end{array}$ & \\
\hline $\begin{array}{c}\text { Hearing } \\
\text { and/or } \\
\text { visual } \\
\text { impairment }\end{array}$ & $\begin{array}{c}506 \\
(17.4)\end{array}$ & $\begin{array}{l}1,041 \\
(35.9)\end{array}$ & $\begin{array}{l}1,350 \\
(46.6)\end{array}$ & \\
\hline $\begin{array}{c}\text { Intellectual } \\
\text { disability }\end{array}$ & $\begin{array}{c}322 \\
(37.4)\end{array}$ & $\begin{array}{c}311 \\
(36.2)\end{array}$ & $\begin{array}{c}226 \\
(26.3)\end{array}$ & \\
\hline
\end{tabular}

There was a significant difference in answers regarding subjective health status $(p<.001)$. Among persons with physical impairment, brain lesions, and hearing and/or visual impairment, the majority reported the status to be "bad," followed by "average" and "good." In contrast, the majority of those with intellectual disabilities reported the status to be "good," followed by "average" and "bad."

The past year's exercising status for health management is presented in Table 2. 
Table 2. Exercising for health management in the past year.

\begin{tabular}{|c|c|c|c|}
\hline $\begin{array}{l}\text { Type of } \\
\text { disability }\end{array}$ & $\begin{array}{l}\text { Yes } \\
(\%)\end{array}$ & $\begin{array}{l}\text { No } \\
(\%)\end{array}$ & $\begin{array}{c}\text { Chi-square } \\
\text { p-value }\end{array}$ \\
\hline $\begin{array}{c}\text { Physical } \\
\text { impairment }\end{array}$ & $\begin{array}{l}4,001 \\
(59.8)\end{array}$ & $\begin{array}{l}2,682 \\
(40.1)\end{array}$ & \multirow{4}{*}{$\mathrm{P}<0.001$} \\
\hline Brain lesions & $\begin{array}{c}736 \\
(53.4)\end{array}$ & $\begin{array}{c}640 \\
(46.5)\end{array}$ & \\
\hline $\begin{array}{c}\text { Hearing and/or } \\
\text { visual } \\
\text { impairment }\end{array}$ & $\begin{array}{l}1,782 \\
(61.5)\end{array}$ & $\begin{array}{l}1,115 \\
(38.4)\end{array}$ & \\
\hline $\begin{array}{c}\text { Intellectual } \\
\text { disability }\end{array}$ & $\begin{array}{c}477 \\
(55.5)\end{array}$ & $\begin{array}{c}382 \\
(44.4)\end{array}$ & \\
\hline
\end{tabular}

There was a significant difference in answers regarding exercising for health management in the past year $(p<.001)$. For all the four types, about $57 \%$ answered positively for participation, while nearly $43 \%$ answered negatively (non-participation).

For those answering negatively regarding regular exercise/participation in PA (Table 2), the reasons are presented in Table 3.

Table 3. Reasons for not participating in regular exercise.

\begin{tabular}{|c|c|c|c|c|c|}
\hline $\begin{array}{l}\text { Type of } \\
\text { disability }\end{array}$ & $\begin{array}{l}\text { Lack } \\
\text { of } \\
\text { funds } \\
\text { and/or } \\
\text { time } \\
(\%)\end{array}$ & $\begin{array}{l}\text { Difficulty } \\
\text { in } \\
\text { accessing } \\
\text { facilities } \\
(\%)\end{array}$ & $\begin{array}{l}\text { Lack of } \\
\text { disability- } \\
\text { related } \\
\text { support } \\
(\%)\end{array}$ & $\begin{array}{c}\text { Other } \\
\text { reasons } \\
(\%)\end{array}$ & $\begin{array}{c}\text { Chi- } \\
\text { square } \\
\text { p-value }\end{array}$ \\
\hline $\begin{array}{c}\text { Physical } \\
\text { impairment }\end{array}$ & $\begin{array}{c}994 \\
(35.3) \\
\end{array}$ & $997(37.3)$ & $264(9.8)$ & $\begin{array}{c}466 \\
(17.4) \\
\end{array}$ & \multirow{4}{*}{$\mathrm{P}<0.001$} \\
\hline $\begin{array}{l}\text { Brain } \\
\text { lesions }\end{array}$ & $\begin{array}{c}55 \\
(8.6) \\
\end{array}$ & $490(77.0)$ & $32(5.0)$ & $\begin{array}{c}59 \\
(9.2)\end{array}$ & \\
\hline $\begin{array}{c}\text { Hearing } \\
\text { and/or } \\
\text { visual } \\
\text { impairment } \\
\end{array}$ & $\begin{array}{c}407 \\
(36.6)\end{array}$ & $352(31.6)$ & $172(15.4)$ & $\begin{array}{c}181 \\
(16.2)\end{array}$ & \\
\hline $\begin{array}{c}\text { Intellectual } \\
\text { disability }\end{array}$ & $\begin{array}{c}70 \\
(18.3)\end{array}$ & $139(36.3)$ & 95 (24.8) & $\begin{array}{c}78 \\
(20.4)\end{array}$ & \\
\hline
\end{tabular}

There was a significant difference in answers regarding the reasons for not participating in regular exercise $(p<.001)$. Among persons with physical impairment, brain lesions, and intellectual disabilities, the majority reported problems with access and movement to facilities, whereas among persons with hearing and/or visual impairment, the main reason was a lack of funds and/or time.

For those answering positively regarding regular exercise/participation in PA (Table 2), the weekly frequencies are presented in Table 4.

Table 4. Weekly exercise frequency.

\begin{tabular}{|c|c|c|c|c|}
\hline $\begin{array}{l}\text { Type of } \\
\text { disability }\end{array}$ & $\begin{array}{c}\text { Once } \\
\text { a } \\
\text { week } \\
\text { or } \\
\text { less } \\
(\%)\end{array}$ & $\begin{array}{c}2-3 \\
\text { times } \\
\text { a } \\
\text { week } \\
(\%)\end{array}$ & $\begin{array}{c}4 \text { or } \\
\text { more } \\
\text { times } \\
\text { a } \\
\text { week } \\
(\%)\end{array}$ & $\begin{array}{l}\text { Chi- } \\
\text { square } \\
\text { p-value }\end{array}$ \\
\hline $\begin{array}{c}\text { Physical } \\
\text { impairment }\end{array}$ & $\begin{array}{c}166 \\
(5.6)\end{array}$ & $\begin{array}{c}748 \\
(25.5)\end{array}$ & $\begin{array}{l}2,009 \\
(68.7)\end{array}$ & \multirow{4}{*}{$\mathrm{P}<0.001$} \\
\hline Brain lesions & $\begin{array}{c}10 \\
(1.6)\end{array}$ & $\begin{array}{c}89 \\
(14.7)\end{array}$ & $\begin{array}{c}506 \\
(83.6)\end{array}$ & \\
\hline $\begin{array}{c}\text { Hearing and/or } \\
\text { visual } \\
\text { impairment }\end{array}$ & $\begin{array}{c}64 \\
(4.6)\end{array}$ & $\begin{array}{c}300 \\
(21.9)\end{array}$ & $\begin{array}{l}1,000 \\
(73.3)\end{array}$ & \\
\hline $\begin{array}{c}\text { Intellectual } \\
\text { Disability }\end{array}$ & $\begin{array}{c}16 \\
(4.5)\end{array}$ & $\begin{array}{c}101 \\
(28.6)\end{array}$ & $\begin{array}{c}236 \\
(66.8)\end{array}$ & \\
\hline
\end{tabular}

There was a significant difference in answers regarding the frequency of weekly exercise/participation in PA $(p<.001)$. However, for all the four types, $66.8 \%$ reported participating four times a week or more, followed by 2-3 times a week, and once a week or less.

For those answering positively regarding regular exercise/participation in PA (Table 2), the time per session is presented in Table 5 .

Table 5. Exercise time per session.

\begin{tabular}{|c|c|c|}
\hline $\begin{array}{c}\text { Type of } \\
\text { disability }\end{array}$ & $\begin{array}{c}\text { Time (min) } \\
(\text { mean } \pm \text { SD) }\end{array}$ & $\begin{array}{c}\text { Chi- } \\
\text { square } \\
\text { p-value }\end{array}$ \\
\hline $\begin{array}{c}\text { Physical } \\
\text { impairment }\end{array}$ & $55.8(42.7)$ & \\
\hline $\begin{array}{c}\text { Brain } \\
\text { lesions }\end{array}$ & $53.4(40.8)$ & \\
\hline $\begin{array}{c}\text { Hearing } \\
\text { and/or } \\
\text { visual }\end{array}$ & $56.7(45.0)$ & \\
impairment & & \\
\cline { 1 - 2 } $\begin{array}{c}\text { Intellectual } \\
\text { disability }\end{array}$ & $55.9(35.7)$ & \\
\hline
\end{tabular}

The survey showed the exercise time per session as $55.9( \pm 42.7), 53.4( \pm 40.8), 56.7( \pm 45)$, and 55.9 $( \pm 35.7)$ minutes for persons with physical impairment, brain lesions, hearing and/or visual impairment and intellectual disability, respectively, with no statistical significance between the types $(p<.001)$. 
For those answering positively regarding regular exercise/participation in PA (Table 2), the preferred places are presented in Table 6 .

Table 6. Preferred places for exercise/PA.

\begin{tabular}{|c|c|c|c|c|c|}
\hline $\begin{array}{c}\text { Type of } \\
\text { disability }\end{array}$ & $\begin{array}{c}\text { Home } \\
(\%)\end{array}$ & $\begin{array}{l}\text { Outdoor } \\
\text { parks/ } \\
\text { neighboring } \\
\text { hiking } \\
\text { trails } \\
(\%)\end{array}$ & $\begin{array}{l}\text { Welfare/ } \\
\text { sports } \\
\text { center } \\
\text { for } \\
\text { people } \\
\text { with } \\
\text { disabilities } \\
(\%)\end{array}$ & $\begin{array}{l}\text { Commer } \\
\text { cial } \\
\text { sports } \\
\text { facilities } \\
\text { and } \\
\text { others } \\
(\%)\end{array}$ & $\begin{array}{c}\text { Chi- } \\
\text { square } \\
\text { p-value }\end{array}$ \\
\hline $\begin{array}{l}\text { Physical } \\
\text { impairment }\end{array}$ & $\begin{array}{l}363 \\
(9.8)\end{array}$ & $\begin{array}{l}2,991 \\
(80.7)\end{array}$ & $\begin{array}{c}174 \\
(4.7)\end{array}$ & $176(4.7)$ & \multirow{4}{*}{$\mathrm{P}<0.001$} \\
\hline $\begin{array}{l}\text { Brain } \\
\text { lesions }\end{array}$ & $\begin{array}{c}77 \\
(11.0) \\
\end{array}$ & $571(81.5)$ & $32(4.5)$ & $20(2.8)$ & \\
\hline $\begin{array}{c}\text { Hearing } \\
\text { and/or } \\
\text { visual } \\
\text { impairment }\end{array}$ & $\begin{array}{c}115 \\
(6.8)\end{array}$ & $\begin{array}{l}1,425 \\
(85.2)\end{array}$ & $73(4.3)$ & $59(3.5)$ & \\
\hline $\begin{array}{l}\text { Intellectual } \\
\text { disability }\end{array}$ & $\begin{array}{c}34 \\
(7.7)\end{array}$ & $341(77.3)$ & $34(7.7)$ & $32(7.2)$ & \\
\hline
\end{tabular}

There was a significant difference in answers regarding the preferred place of exercise/PA $(p<.001)$. However, although there was a significant difference in the response rate for persons with each type of disability, the most preferred places for all the four types were outdoor parks and neighboring hiking trails, followed by home, welfare/sports centers, and commercial facilities.

This is the first study to examine exercise participation patterns and obstacle factors by disability types among a large sample of Koreans. Unlike intellectual disabilities, physical impairments, brain lesions, and hearing and/or visual impairments were subjectively evaluated as poor health, which might be related to physical limitations.

In the questionnaire about participation in regular exercise for health management, about $43 \%$ of all types reported not exercising regularly, which is much higher than the percentage of approximately $21 \%$ in previous reports on the prevalence of physical inactivity in 76 countries [16]. Therefore, additional approaches are necessary to promote PA among people with disabilities.

Additionally, answers from people with most disability types focused on difficulties of access and movement to facilities. This is in line with the opinion of James H. Rimmer [15], who states that persons with disabilities' low participation rate in PA is attributable to a disability-unfriendly environment.

Contrarily, among those who responded positively about regular participation, the majority reported weekly frequencies of four times or more, with time per session of more than 50 minutes each time, regardless of the type of disability. These results contradict those of previous studies reporting a low level of PA and physical fitness among people with disabilities [11,17].

Previous studies have reported a low correlation between objective measurements of PA and those made through self-reported questionnaires, as well as the need to carefully analyze, without overestimating the physical activity of people with disabilities. [18]. Therefore, in future analyses, data collection through objective measurement is recommended to better understand the level of PA among people with disabilities.

Finally, although response frequencies varied by types of disability, the results showed that persons belonging to all the four categories primarily preferred a neighboring outdoor park or hiking trail to a specialized facility. It cannot be overlooked, that similar to those reporting non-participation, those who exercise regularly may also have difficulty accessing specialized facilities. Therefore, additional research is needed in the future to understand the reasons for each response.

This study has several limitations. First, unlike international PA questionnaires that use continuous variables, this survey mainly used nominal scales, making it difficult to determine the level of PA and compare it with that of healthy adults using international PA questionnaires. Second, the selfreported questionnaires may have overestimated the participation of people with disabilities in PA.

\section{Conclusion}

This study analyzed and compared exercise participation patterns and obstacle factors by classifying a large sample of Koreans with disabilities based on their disability types. A subjective evaluation of health status, reasons for not exercising, and participation patterns showed different response frequencies that varied with the type of disability. However, irrespective of the type of disability, it was confirmed that for PA, most people with disabilities preferred neighboring parks, outdoor spaces, or hiking trails to dedicated welfare or sports centers. Therefore, future public health policies should closely identify the characteristics of each type of disability to help promote PA for all. 


\section{REFERENCES}

[1] Ekelund, U., Tarp, J., Steene-Johannessen, J., Hansen, B. H., Jefferis, B., Fagerland, M. W., . . . Lee, I.-M. (2019). Dose-response associations between accelerometry measured physical activity and sedentary time and all cause mortality: systematic review and harmonised meta-analysis. Bmj, 366, 14570. doi:10.1136/bmj.14570

[2] Lear, S. A., Hu, W., Rangarajan, S., Gasevic, D., Leong, D., Iqbal, R., . . . Yusuf, S. (2017). The effect of physical activity on mortality and cardiovascular disease in 130000 people from 17 high-income, middle-income, and low-income countries: the PURE study. Lancet, 390(10113), 2643-2654. doi:10.1016/s0140-6736(17)31634-3

[3] McPhee, J. S., French, D. P., Jackson, D., Nazroo, J., Pendleton, N., \& Degens, H. (2016). Physical activity in older age: perspectives for healthy ageing and frailty. Biogerontology, 17(3), 567-580. doi:10.1007/s10522-016-9641-0

[4] Reiner, M., Niermann, C., Jekauc, D., \& Woll, A. (2013). Long-term health benefits of physical activity-a systematic review of longitudinal studies. BMC Public Health, 13, 813. doi:10.1186/1471-2458-13813

[5] Penedo, F. J., \& Dahn, J. R. (2005). Exercise and well-being: a review of mental and physical health benefits associated with physical activity. Current Opinion in Psychiatry, 18(2). Retrieved from https://journals.lww.com/copsychiatry/Fulltext/2005/03000/Exercise_and_well_b eing_a review_of_mental_and.13.aspx

[6] Walsh, N. P., Gleeson, M., Shephard, R. J., Gleeson, M., Woods, J. A., Bishop, N., . . . Hoffman-Goete, L. (2011). Position statement part one: immune function and exercise.

[7] Woods, J. A., Hutchinson, N. T., Powers, S. K., Roberts, W. O., Gomez-Cabrera, M. C., Radak, Z., . . . Ji, L. L. (2020). The COVID-19 pandemic and physical activity. Sports Medicine and Health Science, 2(2),

doi:https://doi.org/10.1016/j.smhs.2020.05.006

[8] Physical Activity Guidelines Advisory Committee. (2018). 2018 physical activity guidelines advisory committee scientific report. In: : US Department of Health and Human Services

[9] U.S. Department of Health and Human Services. (2019). Physical Activity Guidelines for Americans 2nd edition. Retrieved from https://health.gov/sites/default/files/2019. 09/Physical_Activity_Guidelines_2nd_edition.pdf

[10] Carroll, D. D., Courtney-Long, E. A., Stevens, A. C., Sloan, M. L., Lullo, C., Visser, S. N., . . . Prevention. (2014). Vital signs: disability and physical activity-United States, 2009-2012. MMWR. Morbidity and mortality weekly report, 63(18), 407-413. Retrieved from https://pubmed.ncbi.nlm.nih.gov/24807240

[11] Centers for Disease Control and Prevention. (2007). Physical activity among adults with a disabilityUnited States, 2005. MMWR Morb Mortal Wkly Rep 2007, 56(1021-1024).
[12] Rimmer, J. H., Schiller, W., \& Chen, M.-D. (2012). Effects of Disability-Associated Low Energy Expenditure Deconditioning Syndrome. Exercise and sport sciences reviews, 40(1). Retrieved from https://journals.lww.com/acsm-

essr/Fulltext/2012/01000/Effects_of_Disability_Asso ciated_Low_Energy.5.aspx

[13] Rimmer, J. H., Chen, M.-D., McCubbin, J. A., Drum, C., \& Peterson, J. (2010). Exercise Intervention Research on Persons with Disabilities: What We Know and Where We Need to Go. American Journal of Physical Medicine \& Rehabilitation, 89(3), 249263. doi:10.1097/PHM.0b013e3181c9fa9d

[14] Rimmer, J. H., \& Marques, A. C. (2012). Physical activity for people with disabilities. The lancet, 380(9838), 193-195.

[15] Rimmer, J. H. (2005). The Conspicuous Absence of People with Disabilities in Public Fitness and Recreation Facilities: Lack of Interest or Lack of Access? American Journal of Health Promotion, 19(5), 327-329. doi:10.4278/0890-1171-19.5.327

[16] Dumith, S. C., Hallal, P. C., Reis, R. S., \& Kohl, H. W. (2011). Worldwide prevalence of physical inactivity and its association with human development index in 76 countries. Preventive Medicine, 53(1), 2428. doi:https://doi.org/10.1016/j.ypmed.2011.02.017

[17] Hilgenkamp, T. I. M., Reis, D., van Wijck, R., \& Evenhuis, H. M. (2012). Physical activity levels in older adults with intellectual disabilities are extremely low. Research in Developmental Disabilities, 33(2), 477-483. doi:https://doi.org/10.1016/j.ridd.2011.10.011

[18] van den Berg-Emons, R. J., L'Ortye, A. A., Buffart, L. M., Nieuwenhuijsen, C., Nooijen, C. F., Bergen, M. P., . . . Bussmann, J. B. (2011). Validation of the Physical Activity Scale for Individuals With Physical Disabilities. Archives of physical medicine and rehabilitation, 92(6), 923-928. doi:https://doi.org/10.1016/j.apmr.2010.12.006 